\title{
Investigation of Imperfections Formed at the Ultrasonic Welding of Copper Sheets
}

\author{
Tünde Anna KOVÁCS \\ Óbuda University, Donát Bánki Faculty of Mechanical and Safety Engineering, Department of Materials \\ Technology, Budapest, Hungary, kovacs.tunde@bgk.uni-obuda.hu
}

\begin{abstract}
Ultrasonic welding is a very useful and simple welding process. It is suitable for establishing a joint between thin sheets and dissimilar metals with short preparation and finish work time [1]. Some welding defects were detected due to less than optimal ultrasonic welding parameters. These defects were ruptures, surface colour change and unacceptable deformations. This article aims to identify these failures and their causes.
\end{abstract}

Keywords: copper, ultrasonic welding, weld imperfections, heat affected zone.

\section{Introduction}

The thin sheet welding process specification is an industrial requirement. The applicable processes in the joining of thin metal sheets are brazing, soldering, adhesive bonding and welding. To maintain good conductivity of the metal it is necessary to establish a metalloid joint by welding. It is important to assure the consistency of the welded joint, heat affected zone and the base material microstructure, chemical composition and mechanical properties. In the case of welding defects in the joint, it is necessary to inspect the process specification and modify the technology parameters or change the process.

Ultrasonic welding is advantageous in the electronics industry because in the joining process the generated heat is small and does not need any filler metal. The established joint is metallic with suitable mechanical properties and without significant deformation.

\section{Theoretical background}

\subsection{Fatigue, fatigue strength}

The cracking and the fracture of metals is usually explained as being due to fatigue. In the case of nonferrous and non-titanium base metal alloys
(Al, $\mathrm{Mg}, \mathrm{Cu}$ ) a useful mechanical property is the fatigue strength. The fatigue strength is a strength level, which under definite repetition number (107) is suitable for sizing (Figure 1.) shows the fatigue strength curve without an asymptote. Fatigue strength depends on the grain size, corrosion, frequency and vacuum attendance, the middle stress, plasticity, surface roughness, microstructure (crack sensitivy) and the temperature [3]. The temperature increase causes a decrease in the fatigue strength.

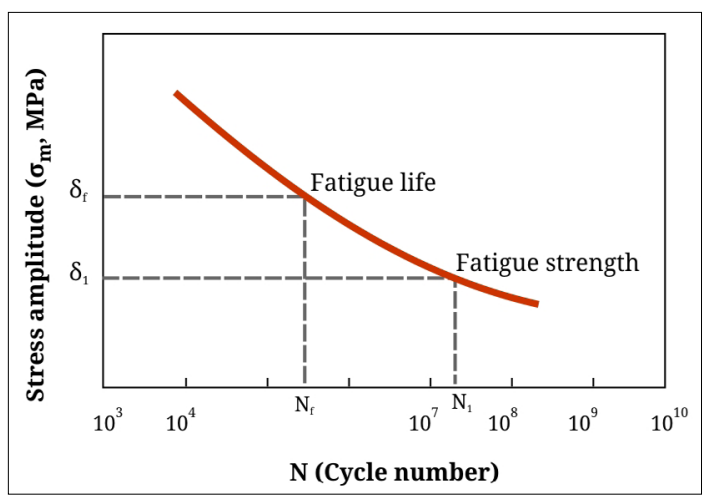

Figure 1. Fatigue strength [2] 


\subsection{Theoretical background of ultrasonic welding}

Ultrasonic welding is not a new welding process, it was introduced many years ago, yet even now the material science background of this bonding process is not well understood. Ultrasonic welding is a solid state welding process, one which is useful for joining thin sheets. The joint is established by pressure and high frequency ultrasound.

The theory of the ultrasound effect for the dislocation movement is known in cold metal working technology.

The basis of ultrasonic welding is the plasticity increasing phenomenon affected by ultrasound vibration because the welded joint is formed by plastic deformation [4-6].
Figure 3. shows the dislocation intensity and microhardness changes as a function of ultrasound actiontime. This theory is one of the reasons for the change in mechanical properties.

The established heat depends on the material's physical properties and the welding parameters. In the case of the aluminium and copper sheets, a high level of heat increase was detected. The welding process is shown in Figure 4.).

It was verified by measurement that during the copper ultrasonic welding, the temperature of the joint reached $500{ }^{\circ} \mathrm{C}$. This temperature is higher than the recrystallization temperature. The join is supported by plastic deformation. Figure 5 . shows the imprint of the hammer on the joint surface, and Figure 6. shows the cross section of

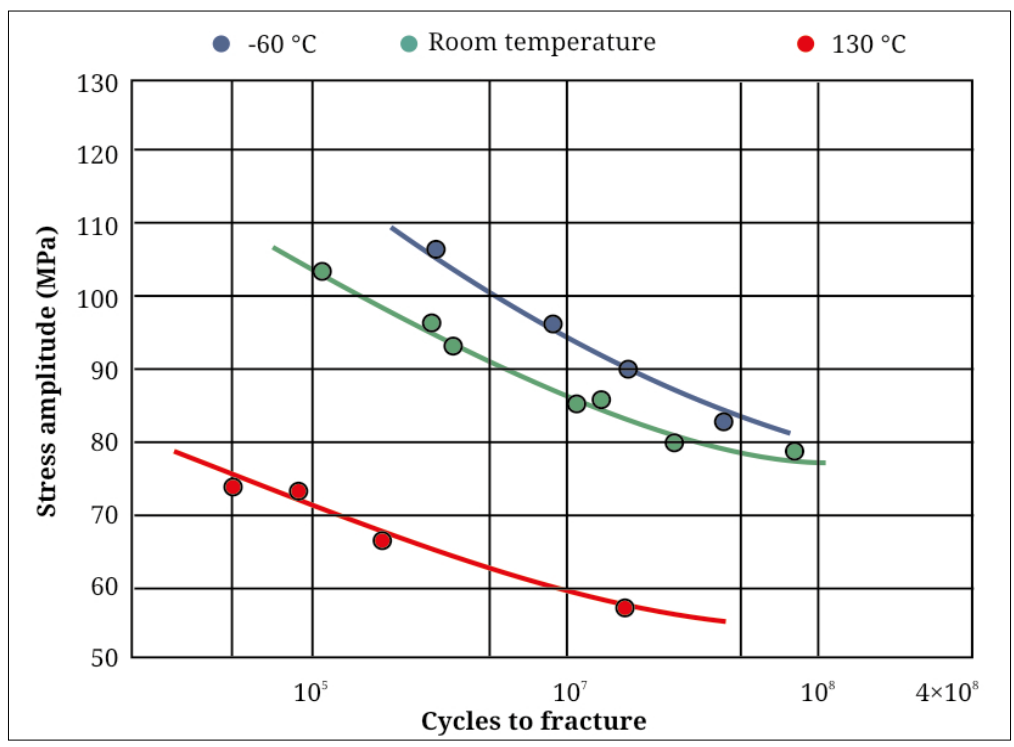

Figure 2. The pure annealed copper fatigue strength function [2]

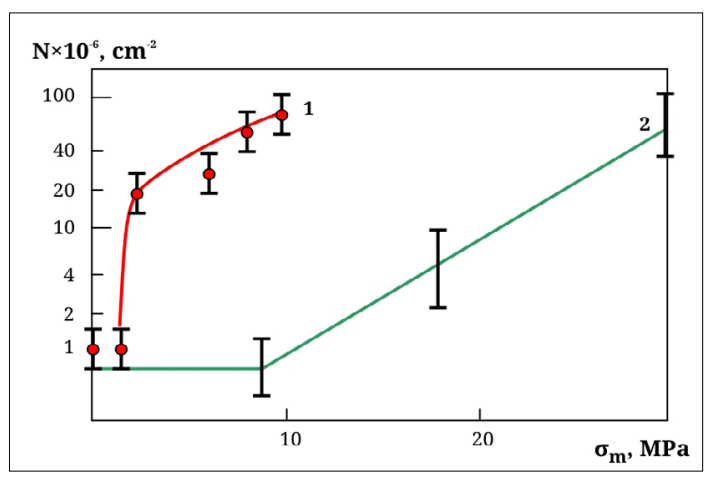

Figure 3. The dislocation intensity as a function of ultrasound stress amplitude(1) $\mathrm{Al} 20^{\circ} \mathrm{C}$, and $\mathrm{Cu} 45{ }^{\circ} \mathrm{C}$ [7]

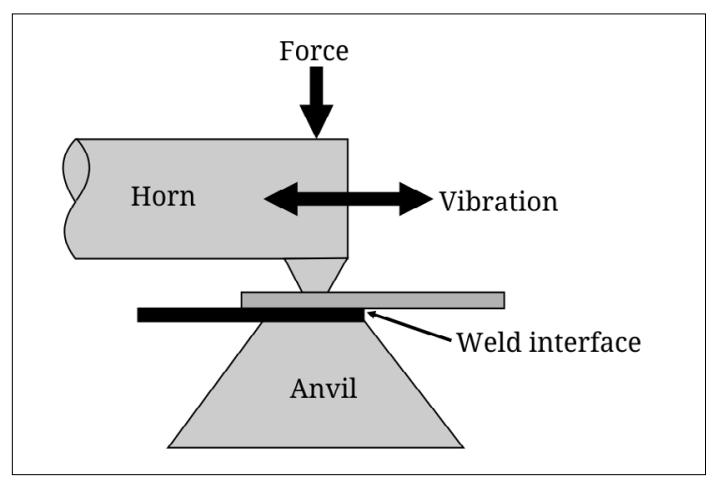

Figure 4. Ultrasonic welding [1] 
the welded joint. The grains are deformed and the grain sizes are different.

In the case of solid state welding the dislocation movement is very important, because this phenomenon supports the plastic deformation which is needed to establish the welded joint. The recrystallization phenomenon produced in the bond by ultrasound and friction generates heat. The grain size in the welded join can change with the mechanical properties. The grain size and the mechanical properties can change in the welded joint.

\section{Investigations of the ultrasonic weld- ed copper sheets}

\subsection{Investigated material}

Copper has always been a very popular metal, being used in the ancient times. It has good plasticity (elongation at rupture $\mathrm{A}=50 \%$ ), good heat and electric conductivity and good corrosion resistance. Its melting temperature $\left(1084^{\circ} \mathrm{C}\right)$ is lower than steels and higher than aluminium. In industrial practice the brazing process is suitable for joining copper sheets because for resistance spot welding special electrodes and work cycle are required, for fusion welding a high temperature is needed. The reflexion and the very good heat conductivity of copper is problematic in the case of low heat input processes such as laser welding [6-7].

Even though copper is a ubiquitously used industrial metal, the strength is low (annealed: $\mathrm{R}_{\mathrm{m}}=240 \mathrm{MPa}, \mathrm{R}_{\mathrm{p} 0.2}=70 \mathrm{MPa}$, hardness $30 \mathrm{HB}$ ). Annealed state copper fatigue strength $62-75 \mathrm{MPa}$ [2]. Cold worked copper strength (380-415 MPa), with alloys and heat treatment is increasable, as against other advantages like electrical conductivity decrease. Applicable in the electrical industry.

Pure copper (CW024A) sheets were used for the investigations, being a common metal for electrical industry applications. Its microstructure is shown in Figure 7. We used annealed copper $(99,90 \%)$ sheets with $0,5 \mathrm{~mm}$ thickness, the sample size was: $15 \mathrm{~mm}$ wide, $60 \mathrm{~mm}$ length (Standard sign: Cu-DHP, EN 1172).

\subsection{The used welding device}

For ultrasonic welding the frequency was constant $\mathrm{f}=20000 \mathrm{~Hz} \pm 50 \mathrm{~Hz}$. The used welding device was the Branson Ultraweld L20. Other parameters were the time of the vibration $t(s)$, and

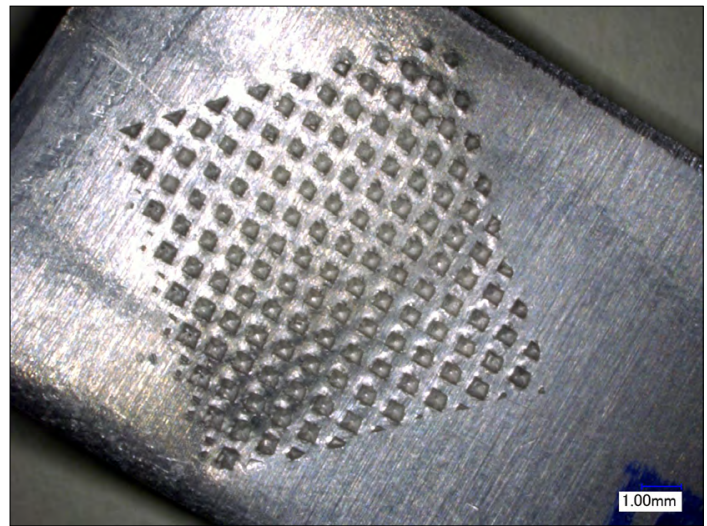

Figure 5. Ultrasonic welded joint surface

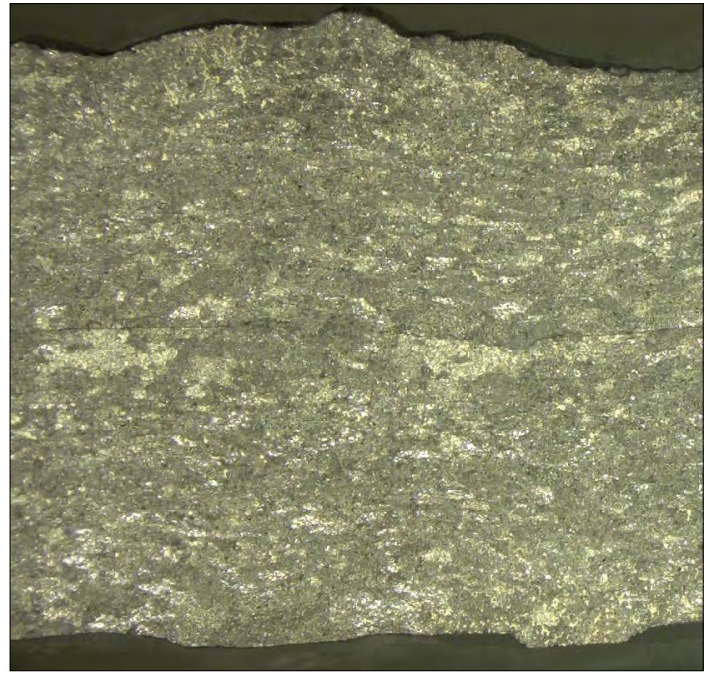

Figure 6. Cross section of the joint (aluminium sample)

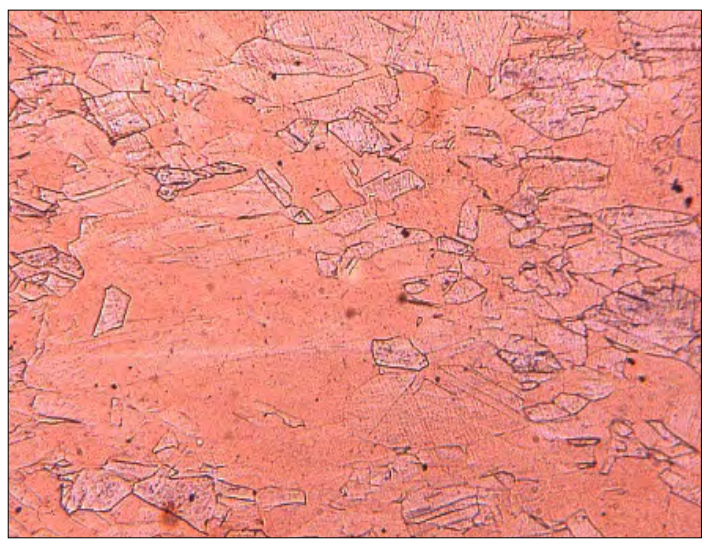

Figure 7. Copper microstructure linear magnification $50 x$, etched by ammonium hydroxide/hydrogen peroxide [7] 
the vibration amplitude $A(\mu \mathrm{m})$, the pressure normal force $F(N)$, the power $P(W)$ from (1) equation, where the $\mathrm{f}(\mathrm{Hz})$ is the frequency:

$$
P=F \cdot A \cdot f
$$

The anvil size was $(12,5 \mathrm{~mm} \times 12,5 \mathrm{~mm}$ square $)$ and the sonotrode size was $(14,5 \mathrm{~mm} \times 12,5 \mathrm{~mm}$ rectangle) the contact area was different. The cooling by air is optional during the welding process.

The welding parameters are readable from the menu system. The energy mode limits the ultrasound effect time to maximal energy. In the case of the time mode the user determines the ultrasound effect duration. The work cycle of the welding process is shown in Figure 8.

In the welding cycle, the trigger pressure takes the sample on the position before welding the welder pressure and the ultrasound affect together establish the welded joint (Figure 4.). The steel anvil and the hammer surfaces are rough to inhibit them joining with the sample [8-9].

\subsection{Investigation of imperfections}

Test welding was carried out using different parameters. In the time mode, the welding time is adjustable. Some pretesting was parformed to determine how the parameters affect intensity of the deformation and joint strength.

The experimental results show that the vibration amplitude and time effects are critical in the joint quality [10]. Figure 9 shows an unsuitable joint. The joint didn't established and in the cross section some cracks were found.

During the welding process the temperature of the samples can increasing high, cause melting in the joint. The Figure 10. shows the melting in the joint cross section. In the case of the ultrasound welded joining this is an unsuitable joint.

Some parameters collectively can affect cracking and rupture, as Figure 11. shows.

The cracks typically proceed from the border of the joint. Figure 11. shows the process affected rupture.

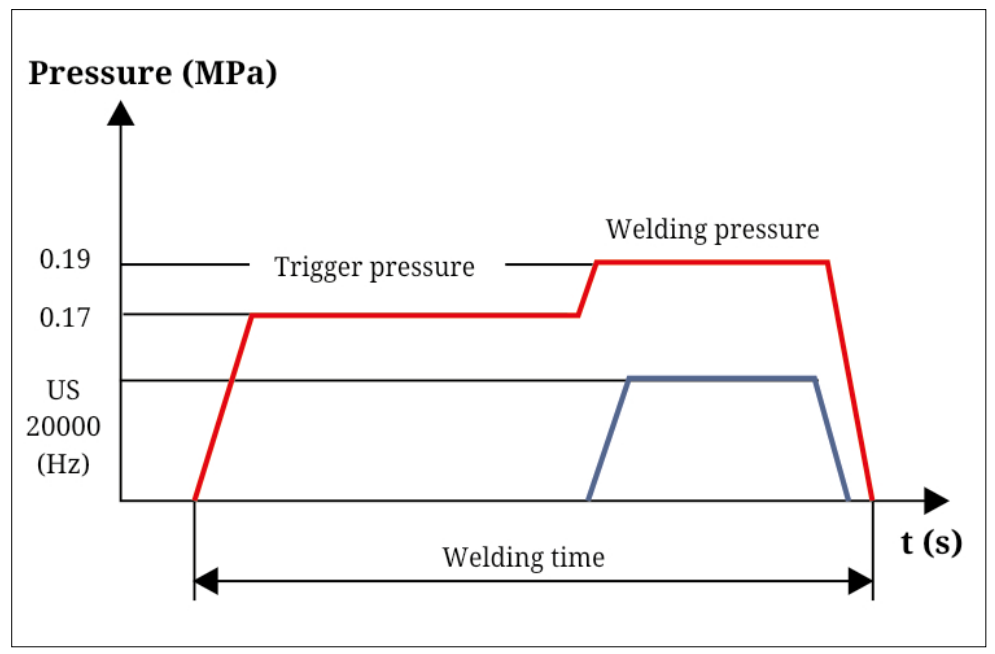

Figure 8. Ultrasonic welding cycle

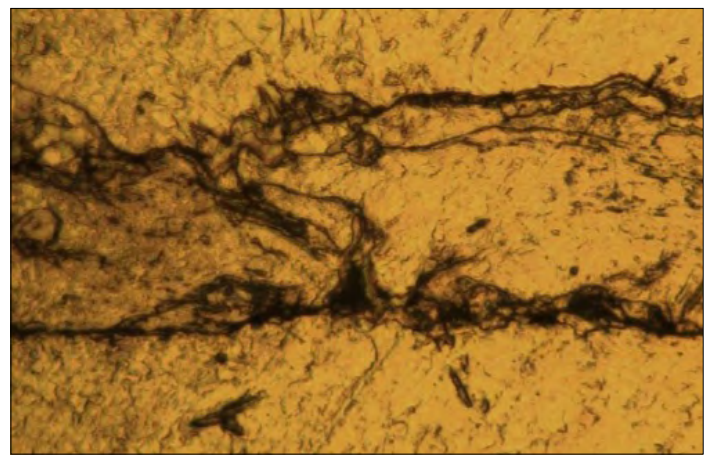

Figure 9. Ultrasonic welded copper joint

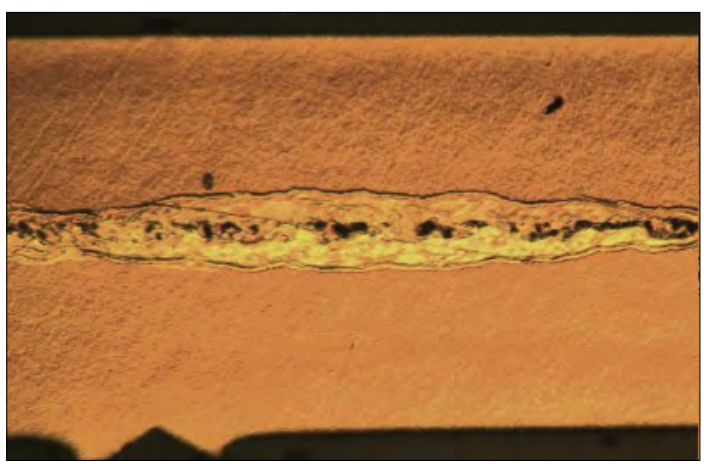

Figure 10. Melted zone in the joint cross section 
The required tests in the case of the ultrasonic welding are the visual test and the tensile test to determine the maximal force. Also required is the investigation of rupture process.

The welding parameters used for the experiments are shown in Table 1 . The trigger pressure (T.P.), and the welding pressure (W.P.) were constant in the experiments $(0,17 \mathrm{MPa})$.

\section{Conclusions}

The results of the experiments are summarized in the Tabel 1. On the basis of the experimental results, it can be concluded that, as function of the welding time, we can detect imperfections (deformation, cracking, changing of the sample color, melting in the joint).

In each case the cracks and crack propagation investigated under long ultrasound effect time. The copper fatigue life time decreases under ultrasound effects.

Surface burning was detected under vibration amplitude and with long welding time. It was concluded also that under high vibration amplitude and short welding time the joint was not suitable.

As a function of the welding time and vibration amplitude, the nascent temperature is determinable, to find this equation requires more experimental results.

\section{Future plan}

We wish to investigate, by experiment, the decrease in copper fatigue life time due to the effects of ultrasound vibration.

More experimental results for the relationship between microstructural changes and resulting mechanical property changes are also the aim of future work.

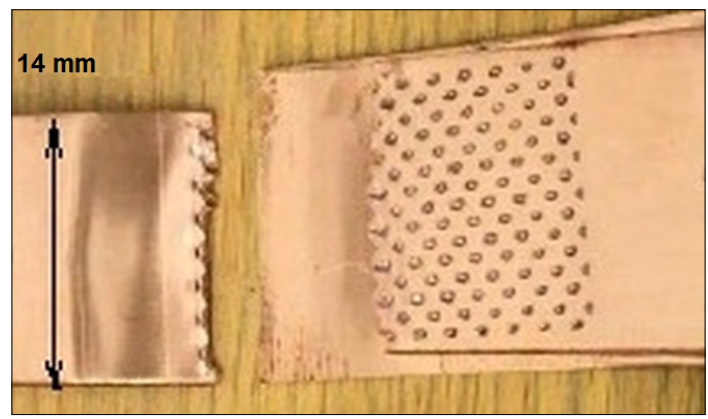

Figure 11. Cracking in the joint
Table 1. The used parameters where; $A$ amplitude $(\mu \mathrm{m}), t$ welding time $(s)$

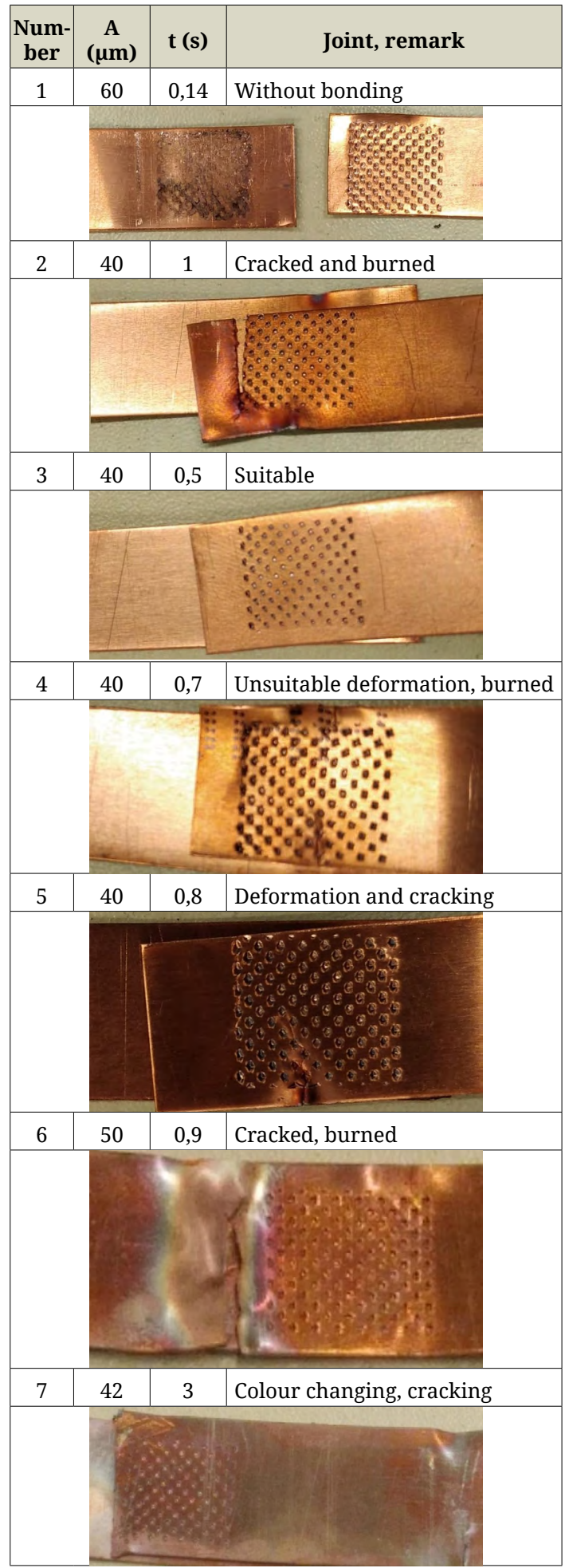




\section{Acknowledgement}

The author wishes to thank Gergely Alvin and Meruyert Rakhimzhan for their assistance in the experiments.

The authors acknowledge the financial support of this work by the Hungarian State and the European Union under the EFOP-3.6.1-16-2016-00010 project.

\section{References}

[1] Bagyinszky Gy., Bitay E.: Ultrahangos hegesztés alkalmazástechnikai jellemzői. In: A XXIII. Fiatal mủszakiak tudományos ülésszak előadásai. Proceedings of the $23^{\text {th }}$ international scientific conference of youngth engineers, Kolozsvár/Cluj, Románia, Müszaki Tudományos Közlemények 7. (2018) 31-34. http://eda.eme.ro/handle/10598/30312

[2] HaikkinenS.:FatigueofMetals, Copper Alloys,2003. http://clic-meeting.web.cern.ch/clic-meeting/2003/06_26sh.pdf

[3] University of Ljubljana: ESDEP oktatási segédlet. 2018. (accessed: 2018. 03. 22.)

http://fgg-web.fgg.uni-lj.si/ /pmoze/esdep/master/wg12/10200.htm

[4] $\mathrm{Wu} \mathrm{X}$ et al.: Microstructure, welding mechanism, and failure of $\mathrm{Al} / \mathrm{Cu}$ ultrasonic welds. Journal of Manufacturing Processes 20. (2015) https://doi.org/10.1016/j.jmapro.2015.06.002
[5] Astashev V. K., Babitsky V. I.: Ultrasonic Processes and Machines, Dynamics, Control and Applications. Springer-Verlag, Berlin-Heidelberg, 2007. 33-45.

[6] Abramov O. V.: High-Intensity Ultrasonics: Theory and Industrial Applications. $1^{\text {st }}$ Edition, CRC Press Published 1999. Januar 18,

[7] Bagyinszki Gy., Bitay E.: Hegesztéstechnika II. Berendezések és mérések. Műszaki Tudományos Füzetek 10., EME, Kolozsvár/Cluj, 2010. 286. http://eda.eme.ro/handle/10598/15438

[8] Langford G.: Microstructures. Massachusetts Institute of Technology, Cambridge, MA, Non Ferrous Alloys 1966. https://www.georgesbasement.com/Microstructures/NonFerrousAlloys/Lesson-1/Specimen01. htm

[9] Bagyinszki Gy., Bitay E.: Hegesztéstechnika I. - Eljárások és gépesítés. Műszaki Tudományos Füzetek 9., EME Kolozsvár/Cluj, 2010. 288. http://eda.eme.ro/handle/10598/15437

[10] Szilágyi M., Kovács T.: Thin aluminium sheets ultrasonic welding. Hegesztéstechnika, Budapest, 2016.

[11] Szilágyi M., Kovács T.: Ultrasonic Welding process in case of aluminium sheets. In: Proceedings of $8^{\text {th }}$ International Engineering Symposium at Bánki, Budapest, 55. (2016). http://bgk.uni-obuda.hu/iesb/2016/publication/55.pdf 